\title{
Role of TGF $\beta$ in regulation of the tumor microenvironment and drug delivery (Review)
}

\author{
PANAGIOTIS PAPAGEORGIS ${ }^{1,2}$ and TRIANTAFYLLOS STYLIANOPOULOS ${ }^{1}$ \\ ${ }^{1}$ Cancer Biophysics Laboratory, Department of Mechanical and Manufacturing Engineering, University of Cyprus, Nicosia 1678; \\ ${ }^{2}$ Department of Health Sciences, Program in Biological Sciences, European University Cyprus, Nicosia 1516, Cyprus
}

Received September 15, 2014; Accepted October 30, 2014

DOI: 10.3892/ijo.2015.2816

\begin{abstract}
Deregulation of cell signaling homeostasis is a predominant feature of cancer initiation and progression. Transforming growth factor $\beta$ (TGF $\beta$ ) is a pleiotropic cytokine, which regulates numerous biological processes of various tissues in an autocrine and paracrine manner. Aberrant activity of TGF $\beta$ signaling is well known to play dual roles in cancer, depending on tumor stage and cellular context. The crucial roles of TGF $\beta$ in modulating the tumor microenvironment, its contribution to the accumulation of mechanical forces within the solid constituents of a tumor and its effects on the effective delivery of drugs are also becoming increasingly clear. In this review, we discuss the latest advances in the efforts to unravel the effects of TGF $\beta$ signaling in various components of the tumor microenvironment and how these influence the generation of forces and the efficacy of drugs. We also report the implications of tumor mechanics in cancer therapy and the potential usage of anti-TGF $\beta$ agents to enhance drug delivery and augment existing therapeutic approaches. These findings provide new insights towards the significance of targeting TGF $\beta$ pathway to enhance personalized tumor treatment.
\end{abstract}

\section{Contents}

1. Introduction

2. TGF $\beta$ synthesis and activation

3. TGF $\beta$ signaling pathways

4. TGF $\beta$ signaling in cancer initiation and tumor progression

5. The effects of TGF $\beta$ on the tumor microenvironment

6. TGF $\beta$, tumor desmoplasia and barriers to drug delivery

Correspondence to: Professor Triantafyllos Stylianopoulos, Cancer Biophysics Laboratory, Department of Mechanical and Manufacturing Engineering, University of Cyprus, Kallipoleos 75, Nicosia 1678, Cyprus

E-mail: tstylian@ucy.ac.cy

Key words: cancer-associated fibroblasts, immune cells, desmoplasia, extracellular matrix, cancer therapy
7. Therapeutic applications of TGF $\beta$ targeting

8. Conclusions and future perspectives

\section{Introduction}

The crucial role of transforming growth factor $\beta$ (TGF $\beta$ ) in tumor progression, metastasis and treatment has been well recognized and has become the topic of extensive research. Among the effects, TGF $\beta$ can regulate cancer cell proliferation, contribute to epithelial-to-mesenchymal transition (EMT), suppress the function of immune cells compromising immune response, contribute to the conversion of fibroblasts to myofibroblasts and cause overproduction of extracellular matrix (ECM) in the tumor. While it has been known for over two decades that anti-cancer drugs cannot penetrate deep into collagen-rich tumors (e.g., pancreatic cancers) and, more significantly, that depletion of collagen fibers can improve drug delivery, only recently TGF $\beta$ has become a target to reduce tumor fibrosis and thus, increase intratumoral drug concentration and treatment efficacy. Preclinical data of this new strategy are promising and it has already reached clinical trials. In this review, we first present a brief description of TGF $\beta$ synthesis and activation along with its signaling pathways. Following, we discuss the effects of TGF $\beta$ on tumor progression, its pathway alterations in cancer as well as its effects on EMT, immune cells function, fibroblasts behavior and ECM remodeling. Finally, based on the above, we review the barriers to the effective delivery of drugs caused by TGF $\beta$ and how regulation of TGF $\beta$ signaling can be employed to optimize delivery of therapeutic agents and overall survival (1-3).

\section{TGFß synthesis and activation}

The TGF $\beta$ superfamily encompasses around 40 secreted cytokines, including TGF $\beta$, bone morphogenetic proteins (BMPs), activins, nodal, lefty, myostatin, anti-Müllerian hormone $(\mathrm{AMH})$ and growth differentiation factors (GDFs). These cytokines regulate a plethora of biological functions such as cell proliferation and apoptosis, embryonic patterning, stem cell maintenance, cell differentiation, migration and immune surveillance. Importantly, the effects of these factors are characterized as cell-type specific as well as context dependent (1-3). The TGF $\beta$ isoforms, with most common 
being TGF $\beta 1,2$ and 3, are initially synthesized as $75 \mathrm{kDa}$ inactive homodimers, known as pro-TGF $\beta$, which consist of TGF $\beta$ associated with latency-associated proteins (LAPs) at the N-terminal part of the pro-peptide. This is part of the TGF $\beta$ large latent complex (LLC), comprised of the LAPs and the latency TGF $\beta$-binding proteins (LTBPs) (4-7), and is covalently associated to the ECM via the $\mathrm{N}$-terminal region of LTBPs $(8,9)$ (Fig. 1). While TGF $\beta$ is part of the LLC complex, it remains in an inactive form since the high affinity association of LAPs with TGF $\beta$ prevents the interaction with its receptors (10). During TGF $\beta$ activation, LAPs undergo conformational changes induced by thrombospondin-1 (TSP-1) $(11,12)$ followed by cleavage mediated by furin convertase, plasmin or matrix metalloproteinases MMP-2/9 resulting in the release of the mature $24 \mathrm{kDa}$ TGF $\beta$ dimer (13-15). The active ligand is then able to bind and activate TGF $\beta$ receptors (TGF $\beta$ Rs) to propagate downstream intracellular signaling events. Therefore, the processing of pro-TGF $\beta$ into the active TGF $\beta$ ligand is a critical regulatory step which determines its bioavailability.

\section{TGF $\beta$ signaling pathways}

The TGF $\beta$ and TGF $\beta$-like cytokines mediate downstream intracellular signaling via the Smad family of proteins, which consists of eight human structurally related members (16-20) (Fig. 1). Smads can be functionally classified into three groups: the receptor activated Smads (R-Smads), which include Smad1, 2, 3, 5, 8; the common mediator Smad (Co-Smad), Smad4; and the inhibitory Smads (I-Smads), Smad6 and 7 (17,21). Three types of TGF $\beta$ Rs are responsible for initiating signaling; TGF $\beta$ RI, II and III. There are seven TGF $\beta$ RI, five TGF $\beta$ RII and two TGF $\beta$ RIII known so far. TGF $\beta$ RIs include activin receptor-like kinases 1-7 (ALK1-7), TGF $\beta$ RIIs include the TGF $\beta$ RII, bone morphogenetic protein receptor II (BMPRII), activin receptor II (ACTRII), ACTRIIB, anti-Müllerian hormone receptor II (AMHRII), while betagycan and endoglin belong to the TGF $\beta$ RIIIs (22) and mostly function as co-receptors to enhance activin signaling (23). In most tissues, TGF $\beta$ ligands function through heteromeric complex formation between two TGF $\beta$ RI and two TGF $\beta$ RII molecules. While both receptors possess Ser/Thr kinase activity, TGF $\beta$ RIIs function as the 'activator' and TGF $\beta$ RIs as the 'signal propagating' component (24). The TGFßRII-ALK5 complex transduces the signal from all three TGF $\beta$ isoforms in multiple cell types, whereas association of TGF $\beta$ RII with ALK1 is involved in endothelial cells and with ALK2 in cardiovascular tissues (25). ALK5 activates Smad2 and 3 via the canonical TGF $\beta$ signaling pathway whereas ALK2, 3 and 6 can activate Smad1, 5 and 8 , which are transducers of the BMP signaling pathway $(26,27)$. The TGF $\beta$ signaling pathways can be classified in two major categories; the canonical or Smad-dependent and the non-canonical or Smad-independent pathways.

Canonical pathway (Smad-dependent). Even though TGF $\beta$ isoforms may elicit diverse cellular responses, they all activate signaling via a similar sequence of events. Binding of the active TGF $\beta 1$ ligand to the Ser/Thr kinase TGF $\beta$ RII followed by recruitment of the ALK5 (TGF $\beta$ RI) on the cell surface initiates intracellular signaling. Within the heterotetrameric receptor-ligand complex formed, TGF $\beta$ RII phosphorylates TGF $\beta$ RI allowing it to interact with the R-Smads (Smad2/3) which, in turn, become phosphorylated at the conserved SSXS C-terminal motif $(28,29)$. Recruitment of R-Smads to the activated TGF $\beta$ RI is facilitated by Smad anchor for receptor activation (SARA) protein (30). Subsequently, this triggers the formation of a heterotrimeric complex between phosphorylated R-Smads (Smad2/3) and Co-Smad (Smad4), which can translocate into the nucleus to regulate gene expression (3) (Fig. 1). Smads can differentially modulate gene expression by acting as transcription factors in co-operation with co-activators, such as $\mathrm{p300/CREB-binding} \mathrm{protein} \mathrm{(CBP),}$ p300/CBP-associated factor (PCAF), Smad4-interacting factor (SMIF), forkhead transcription factors 1, 3, 4 (FoxO1/3/4), specificity protein 1 (Sp1), c-Jun/c-Fos, Sertad1, or co-repressors, such as E2F4/5-p107, activating transcription factor 3 (ATF3), TGF $\beta$-induced factor (TGIF), Ski, SnoN, forkhead transcription factor G1 (FoxG1), ecotropic viral integration site 1 protein (EVI1) and C-terminal binding protein (CTBP) $(28,31-47)$. In addition, Smads are able to epigenetically regulate gene expression either by inducing chromatin remodeling $(48,49)$ or by maintaining DNA methylation and silencing of selected genes (50). Importantly, the I-Smad, Smad7, is a key target gene induced by TGF $\beta$ signaling and acts as negative feedback regulator of the pathway (51). In the absence of TGF $\beta$ stimulation, Smad7 resides in the cell nucleus and translocates to the plasma membrane upon TGF $\beta$-mediated receptor activation (52). Smad7 is then able to interfere and block interactions between the R-Smads and the activated receptors to inhibit downstream signaling events (53). In addition, Smad7 can target the TGF $\beta$ Rs for proteasomal degradation via the E3-ubiquitin ligases Smurf1 and 2 (54,55). Finally, Smad7 antagonizes the formation of a functional Smad-DNA complex by directly binding to DNA via its MH2 domain and therefore blocks TGF $\beta$-mediated transcriptional responses (56).

Non-canonical pathways (Smad-independent). It is also well established that TGF $\beta$-mediated effects can also be exerted through non-canonical Smad-independent pathways (57). TGF $\beta$ has been shown to induce activation of Erk signaling in various tissues including epithelial and endothelial cells, fibroblasts, breast and colorectal cancer cells in order to promote disassembly of adherens junctions and cell migration (58-64). TGF $\beta$ RI phosphorylation can recruit and activate ShcA, thus promoting the formation of a ShcA/Grb2/Sos complex. In turn, this complex is able to activate Ras on the plasma membrane followed by sequential activation of c-Raf, MEK and Erk (65).

Moreover, TGF $\beta$ can mediate the activation of the c-Jun N-terminal kinase (JNK) and p38/mitogen-activated protein kinase (MAPK) pathways, which are responsible for promoting apoptosis or cell migration depending on cellular context (66-68), via the mitogen-activated protein kinase kinase (MKK)4 and 3/6, respectively $(69,70)$. Further upstream, MKKs are phosphorylated by the TGF $\beta$-activated kinase 1 (TAK1) $(71,72)$ which is recruited to the TGF $\beta$ Rs via the scaffold protein TNF receptor-associated factor 6 (TRAF6) $(73,74)$. Besides TAK1, two other 


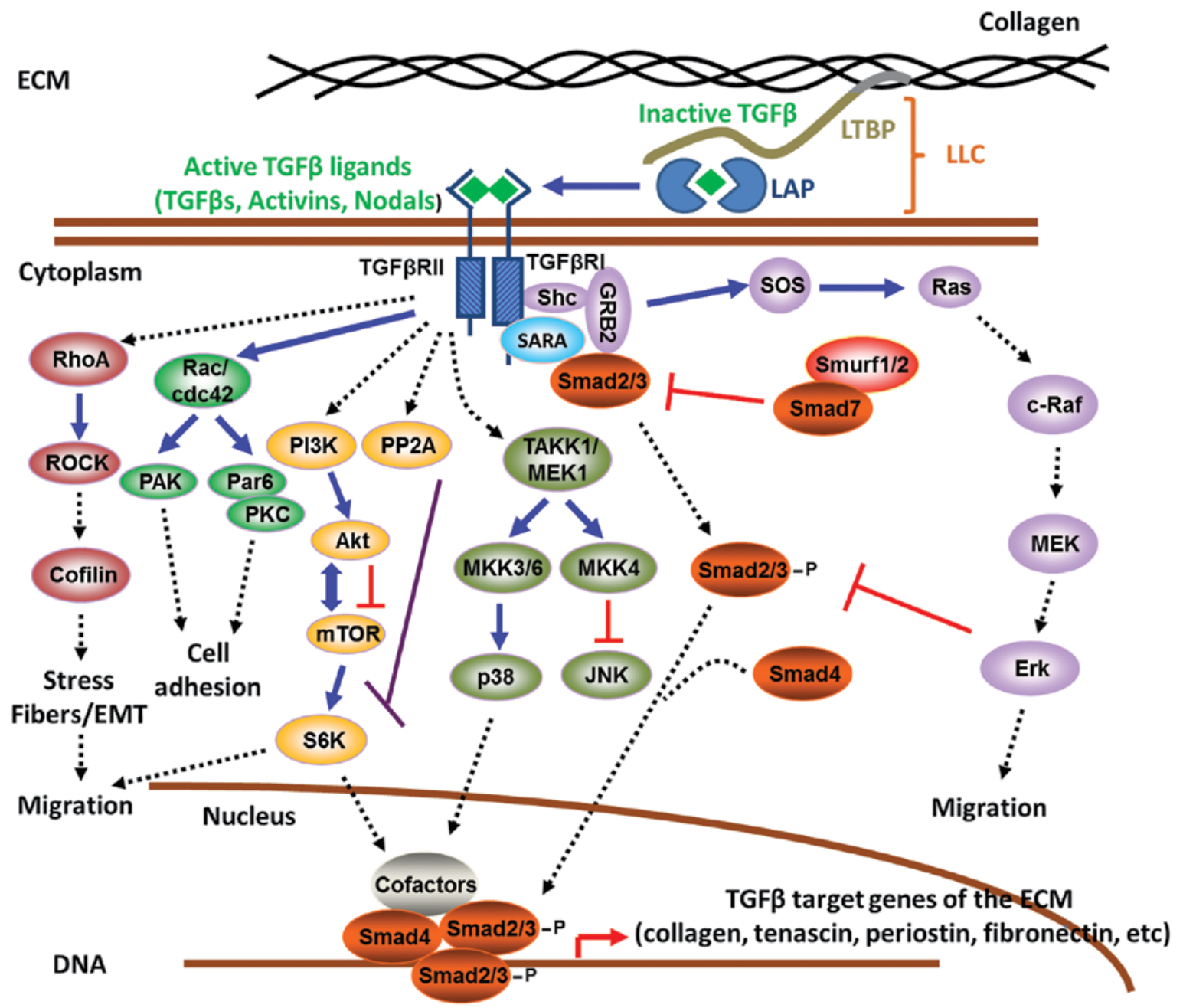

Figure 1. Smad-dependent and -independent transforming growth factor $\beta$ (TGF $\beta$ ) pathways. TGF $\beta$ is initially synthesized and stored in the extracellular matrix (ECM) in an inactive form, as part of the large latent complex (LLC). Upon activation, the released TGF $\beta$ ligands initiate signaling by binding to TGF $\beta$ RIs and TGF $\beta$ RIIs. TGF $\beta$ receptors (TGF $\beta$ Rs) exhibit kinase activities that are necessary for transducing canonical TGF $\beta$ signaling by phosphorylating Smads2/3. Activated receptor-associated Smads can form a heterotrimeric complex with Smad4, which interacts with other co-factors in the nucleus to regulate the expression of $T G F \beta$ target genes. In addition, downstream intracellular signaling may also be transduced via auxiliary pathways including the MEK/Erk, the Rho-like GTPases, the phosphatidylinositol-4,5-bisphosphate 3-kinase/Akt (PI3K/Akt) and the p38/mitogen-activated protein kinase (MAPK) pathways to regulate biological responses such as epithelial-to-mesenchymal transition (EMT), cell adhesion, migration and survival.

mitogen-activated protein kinase kinase kinases (MAPKKKs), namely MEKK1 and mixed lineage kinase 3 (MLK3), were also shown to mediate TGF $\beta$-induced activation of JNK and p38-MAPK by MKK4 and 3/6 (75,76).

The Rho-like small GTPases, predominantly RhoA, Rac and cell division cycle 42 (cdc42), are additional molecules that mediate important TGF $\beta$ cellular functions, such as cytoskeletal organization, cell polarity, cell migration and gene expression (77). TGF $\beta$ is able to rapidly activate the RhoA and cdc42/Rac1 pathways, in a Smad2/3-independent manner, to promote actin polymerization, formation of stress fibers and EMT $(78,79)$. TGF $\beta$ may also downregulate RhoA protein levels by recruitment of Par6 at the TGF $\beta$ RI-II complex. Phosphorylation of Par6 by TGF $\beta$ RII triggers binding of the E3 ligase Smurf1 to the complex followed by ubiquitination and degradation of RhoA at sites of cellular protrusions. Subsequently, this leads to the dissolution of tight junctions, rearrangement of actin cytoskeleton and EMT (80).

Some of the effects exerted by TGF $\beta$ could also be mediated by activation of the phosphatidylinositol-4,5-bisphosphate
3-kinase/Akt (PI3K/Akt) pathway. This is evident from studies showing that TGF $\beta$ can rapidly induce PI3K activation followed by phosphorylation of its effector Akt to promote EMT, cell migration and survival $(81,82)$. One of the most important effector molecules downstream of PI3K/Akt pathway appears to be the mammalian target of rapamycin (mTOR), a key regulator of protein synthesis, which can subsequently phosphorylate S6 kinase (S6K) and eukaryotic initiation factor 4E-binding protein 1 (4EBP1) (83). Activation of the mTOR pathway by TGF $\beta$ is thought to be important for regulating cell size, EMT and invasion (84) (Fig. 1).

\section{TGF $\beta$ signaling in cancer initiation and tumor progression}

It is well established that the multipotent actions of TGF $\beta$ are highly context dependent. The complexity of these functions is increased due to the fact that TGF $\beta$ exerts distinct effects depending on the tissue type as well as the genetic and epigenetic background of cells (85). It is clearly evident that 
TGF $\beta$ plays dual roles during carcinogenesis. In early stages TGF $\beta$ promotes growth inhibition and apoptosis of normal epithelial and lymphoid cells as well as pre-malignant tumors, whereas during late stages TGF $\beta$ acquires pro-oncogenic and pro-metastatic roles, which are associated with a progressive increase in the locally secreted TGF $\beta$ levels (86-88). Therefore, one of the hallmarks of cancer is that the vast majority of cases exhibits insensitivity to TGF $\beta$-mediated growth inhibition.

Regulation of cell proliferation. It has long been noted that TGF $\beta$ has a cytostatic effect on normal epithelial (89), endothelial $(90,91)$ and neuronal cells $(92)$ as well as certain cells of the immune system, such as T cells (93). These functions of TGF $\beta$ are extremely important for physiological tissue homeostasis in order to restrain cell proliferation and prevent the generation of hyperproliferative disorders, like cancer. These anti-proliferative effects primarily control the G1/S phase transition events (94) and are mediated via induction of the cyclin-dependent kinase inhibitors $C D K N 2 B$ (encoding p15/INK4B) (95), CDKN1A (encoding p21/Cip/Waf1) (96) and p27/Kipl (97) by TGF $\beta$. Cell cycle arrest can also be achieved by repression of the proliferation-inducing transcription factors c-Myc (98) and the family of inhibitor of DNA-binding proteins ID1, 2 and $3(36,99)$. On the other hand, the effects of TGF $\beta$ in proliferation can be opposing, depending on the tissue type. It is also well recognized that TGF $\beta$ enhances proliferation of fibroblasts (89) and it is often mediated indirectly by TGF $\beta$-induced connective tissue growth factor (CTGF) secretion, which is responsible for stimulating fibroblast proliferation and ECM synthesis (100). It is now unambiguously accepted that cancer-associated fibroblasts (CAFs) play critically important roles in the tumor microenvironment and cancer progression and their functions are further discussed below.

Pathway alterations in human cancers. Numerous human studies have identified that components of the TGF $\beta$ pathway become genetically or epigenetically altered in various tumor types thus explaining, at least in part, the escape from TGF $\beta$-mediated growth control. Loss of function or truncating mutations in TGF $\beta R I$ and $T G F \beta R I I$ as well as in Smad2 and Smad4 have been detected in colorectal, pancreatic, gastric and prostate cancers (18,101-105). In addition, loss of the 18q21 chromosome region, harboring the Smad4 gene, is commonly observed in $\sim 60 \%$ of pancreatic and $30 \%$ of colorectal cancers (106-109) has been shown to promote angiogenesis and tumor growth by inducing vascular endothelial growth factor (VEGF) expression $(60,110)$. However, in other tumor types like breast, the frequency of Smad gene mutations is rare $(18,104,105)$ suggesting that alternative mechanisms for acquiring resistance to growth inhibition by TGF $\beta$ exist. These include activation of the Ras oncogene which leads to Erk-mediated Smad2/3 phosphorylation and suppression of functional Smad complex formation (111-113). Furthermore, overexpression of the dominant-negative CCAAT/enhancer-binding protein $\beta(\mathrm{C} / \mathrm{EBP} \beta)$ isoform LIP in breast cancer patients was found to suppress TGF $\beta$-mediated growth inhibition (114). Finally, another mechanism which TGF $\beta$ may exploit in order to switch from a tumor suppressor to a metastasis-promoting factor is through differential regu- lation of the IDI gene. While ID1 expression is suppressed by TGF $\beta$ in normal tissues, it was found to be induced in patient-derived metastatic breast cancer cells (115).

EMT and cancer metastasis. EMT is an integral process during embryonic development which can be abnormally reactivated in adult tissues under pathological conditions, such as cancer and fibrosis (116). It involves the activation of a coordinated reversible transcriptional program whereby epithelial cells undergo dissolution of cell junctions, lose their polarity and epithelial characteristics concomitantly with acquisition of mesenchymal features and dramatic remodeling of their cytoskeleton. During this process, the expression of epithelial genes, such as E-cadherin, $\gamma$ - and $\beta$-catenin, zonula occludens $(\mathrm{ZO})$, and claudins is suppressed with concurrent expression of mesenchymal components, such as $\mathrm{N}$-cadherin, vimentin, fibronectin and $\alpha$-smooth muscle actin $(\alpha-$ SMA) $(50,117,118)$. This program can be initiated by several pleiotropically acting transcription factors regulated by signaling pathways such as TGF $\beta$, Wnt and receptor tyrosine kinases (RTKs). Some of the better characterized examples include Snail (119), Slug (120), zinc-finger E-box binding

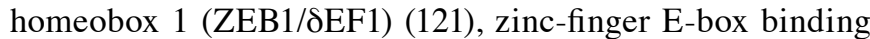
homeobox 2/Smad interacting protein 1 (ZEB2/SIP1) (122), Twist (117), high mobility group AT-hook 2 (HMGA2) (123) and forkhead box protein C2 (FOXC2) (124). In addition, recent studies indicate that overactive TGF $\beta$-TGF $\beta$ R-Smad2 signaling axis could further contribute to the establishment of an EMT phenotype by maintaining the epigenetic silencing of epithelial genes during this process (50). Besides Smads, other signaling pathways have also been implicated in TGF $\beta$-induced EMT, including Erk, PI3K/Akt, RhoA, p38-MAPK and cofilin (125-127). Induction of EMT is one of the major mechanisms by which TGF $\beta$ has been shown to promote cell motility, invasiveness and metastasis of cancer cells (128). EMT significantly enhances intravasation of carcinoma in situ cells through the basement membrane, survival in the circulation, extravasation at the distal tissues and formation of micrometastases in secondary organs $(116,117,129)$.

\section{The effects of TGF $\beta$ on the tumor microenvironment}

Under physiological conditions, the sustained local release of basal TGF $\beta$ levels is sufficient to maintain normal tissue homeostasis. However, under conditions of tissue injury, the local TGF $\beta$ secretion from stromal cells and blood platelets is rapidly increased to facilitate wound repair as well as to prevent uncontrolled regenerative cell proliferation and inflammation $(130,131)$. A similar situation is commonly observed in pre-malignant tumors where TGF $\beta$ is secreted in the microenvironment initially to control proliferation and cancer progression, but it is ultimately utilized by cancer cells to promote their malignant properties. Local TGF $\beta$ release produces a tumor microenvironment which is conducive to tumor growth, invasion and metastasis (132). Secretion of TGF $\beta$ can be derived from epithelial cancer cells thus regulating their own properties within the tumor mass in an autocrine or paracrine fashion (125). Moreover, infiltrating stromal cells, including fibroblasts, leukocytes, macrophages, bone-marrow derived endothelial, mesenchymal and myeloid 
precursor cells, is another major source of this cytokine (133). Finally, TGF $\beta$ can be stored in the ECM of the bone and can be activated during development of osteolytic metastatic lesions (134). In the following paragraphs, we summarize the effects of TGF $\beta$ on the main and better characterized components of the tumor microenvironment and particularly on fibroblasts, immune cells and the ECM.

Effect of TGF $\beta$ on immune cells. TGF $\beta$ exhibits immunosuppressive effects on all arms of the immune system because it functions as antagonist of several functions of the immune cells $(132,135)$. As a result, the anti-tumor immune response is compromised, reducing cancer cell recognition and clearance. Specifically, TGF $\beta$ affects the function of natural killer cells, $\mathrm{CD}^{+}$and $8^{+} \mathrm{T}$ cells, macrophages, neutrophils, dendritic, mast and B cells (136-138). Specifically, a TGF $\beta$-rich tumor microenvironment is a suppressor of T-cell proliferation, reduces their effector function and inhibits the maturation of T helper cells $(137,139,140)$. It also induces macrophage M2 polarization from a type I to a type II phenotype, which hinders the suppression of monocyte-mediated cell death, reduces effector function and increases chemotaxis $(141,142)$. Additionally, TGF $\beta$ induces an N2 neutrophil phenotype which, as with the macrophages, reduces effector function and increases secretion of inflammatory cytokines (143). Finally, high levels of TGF $\beta$ can cause apoptosis of B cells, inhibit the maturation of dendritic and natural killer cells and induce chemotaxis of mast cells (144-146). The combined immunosuppressive effects of TGF $\beta$ compromise the ability of the host to resist tumor progression and thus consist a barrier to immunotherapy.

Effect of TGF $\beta$ on fibroblasts. A primary role of TGF $\beta$ in modulating the tumor microenvironment is its contribution to the conversion of fibroblasts to myofibroblasts, also known as CAFs $(147,148)$. Specifically, the compressive forces developed inside a tumor, due to its growth in the confined space of the host tissue, can facilitate the conversion of fibroblasts to proto-myofibroblasts. Subsequently, TGF $\beta$ increases the levels of collagens I and III and fibronectin, which promote cellular adhesion to extracellular fibers, and thus, enhances the communication of mechanical signals between the ECM of the tumor and the fibroblasts $(149,150)$. As a result, the mechanical forces are more actively transmitted in the interior of the cell and contribute to the conversion of proto-myofibroblasts to differentiated myofibroblasts. Myofibroblasts are characterized by more extensively developed stress fibers in the cytoskeleton compared to proto-myofibroblasts, presumably to balance the extracellular forces, and by the de novo expression of $\alpha$-SMA. The contraction of myofibroblasts is sustained by $\alpha$-SMA stress fibers and it is regulated by Rho/ROCK signaling activation. The produced contractile forces remodel the ECM due to the ability of fibroblasts to stretch collagen fibers and produce ECM molecules $(151,152)$. Additionally, these forces can be transmitted to the LLC via integrins. LLC is also bound to extracellular fibers (Fig. 1), which resists the pulling of the LLC by myofibroblasts and gives rise to a mechanically-induced liberation of TGF $\beta$ (147). The stiffer the ECM, the stronger the interactions among myofibroblasts, LLC and extracellular fibers and thus, the release of TGF $\beta$ becomes more pronounced.
Therefore, myofibroblast contraction within a collagen-rich, and thus, stiff microenvironment further stimulates the release of active TGF $\beta$ from its latent form.

Effect of TGF $\beta$ on ECM. TGF $\beta$ upregulates the expression and synthesis of many matrix proteins, primarily through the recruitment of myofibroblast. Proteins upregulated by TGF $\beta$ include collagens I-V, basement membrane proteins (laminin, entactin, perlecan) and ECM proteins (fibronectin, osteopontin, thrombospontin, tenascin, osteonectin/SPARC, elastin, biglycan, decorin, and hyaluronan) (153). Additionally, in the early stages of carcinogenesis, TGF $\beta$ stimulates myofibroblasts and other stromal cells to enhance the synthesis of collagen crosslinking enzymes, particularly lysyl oxidase, which increases the rigidity of the collagen network (154). On the contrary, TGF $\beta$ downregulates the synthesis of matrix-depleting proteins, such as matrix metalloproteinases (MMP-1, -8, -13). As a result, the increase in matrix protein synthesis and decrease in matrix proteinase activity, owing to the TGF $\beta$ activity, contributes to the remodeling of the tumor ECM and can result in a fibrotic response, known as desmoplasia, which is commonly observed in many types of tumors and particularly in pancreatic, colon and breast cancers as well as in various sarcomas $(155,156)$.

Tumor fibrotic response stiffens the tumor tissue, and as a result, it increases the compressive physical forces in the interior of the tumor (157). Compression of cancer cells alters their gene expression profile to enhance their invasive and metastatic phenotype $(158,159)$. Furthermore, as mentioned previously, matrix stiffening along with the high contractile forces of myofibroblasts, cause further liberation of TGF $\beta$ from the LLC. These events suggest a positive feedback loop between TGF $\beta$ activation, myofibroblast contraction and ECM remodeling and production (Fig. 2A) (148). Finally, compression of intratumoral blood vessels reduces tumor perfusion, and thus, the delivery of oxygen (160). Hypo-perfusion and hypoxia, in turn contribute to immune-evasion, promote malignant progression and metastasis, and reduce the efficacy of a number of therapies including radiation treatment and systemic administration of chemo- and nanotherapy (161-163).

\section{TGF $\beta$, tumor desmoplasia and barriers to drug delivery}

The desmoplastic reaction of solid tumors hinders all three transport steps of the systemic delivery of drugs, namely vascular, transvascular and interstitial transport $(156,163)$. As mentioned above, increased levels of collagen in the ECM, result in intratumoral blood vessel compression and hypo-perfusion. Hypo-perfusion, in turn, reduces the concentration of the drug that can reach the tumor site. Apart from compromised drug delivery, hypo-perfusion also decreases the supply of oxygen rendering the tumor hypoxic, which in turn reduces the efficacy of radiation therapy. Additionally, desmoplasia reduces the hydraulic conductivity of the tumor interstitial space, i.e., the ease with which the interstitial fluid percolates through the interstitial space of a tissue. High hydraulic conductivity allows fluid to rapidly flow in the interstitial space and be drained by peripheral lymphatic vessels. The accumulation of collagen and other ECM proteins in tumors decrease the available spaces for interstitial fluid flow and because the fluid cannot freely 
A

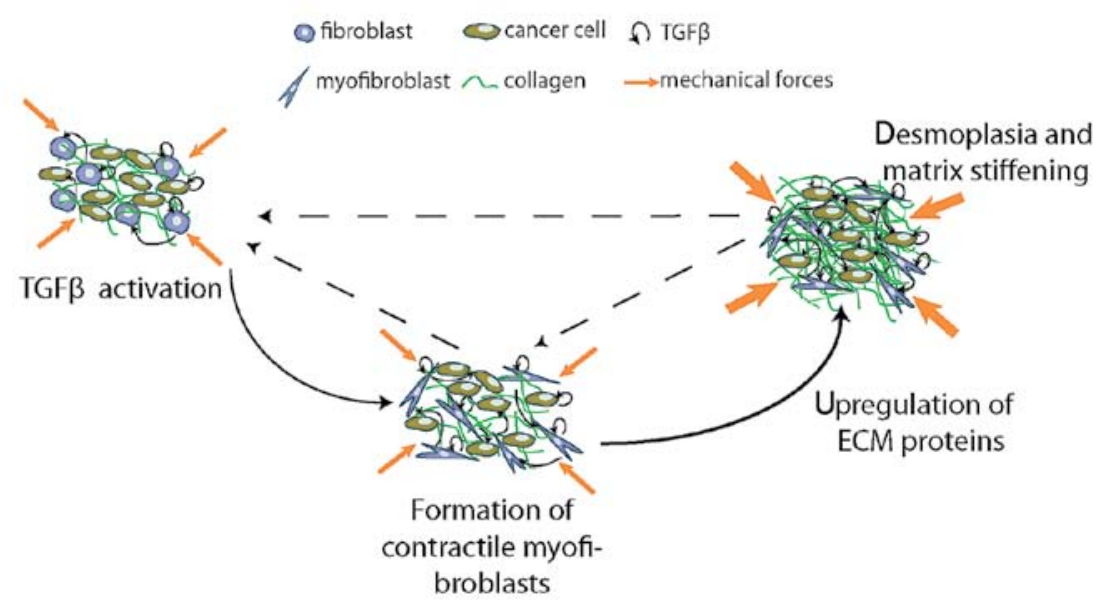

B
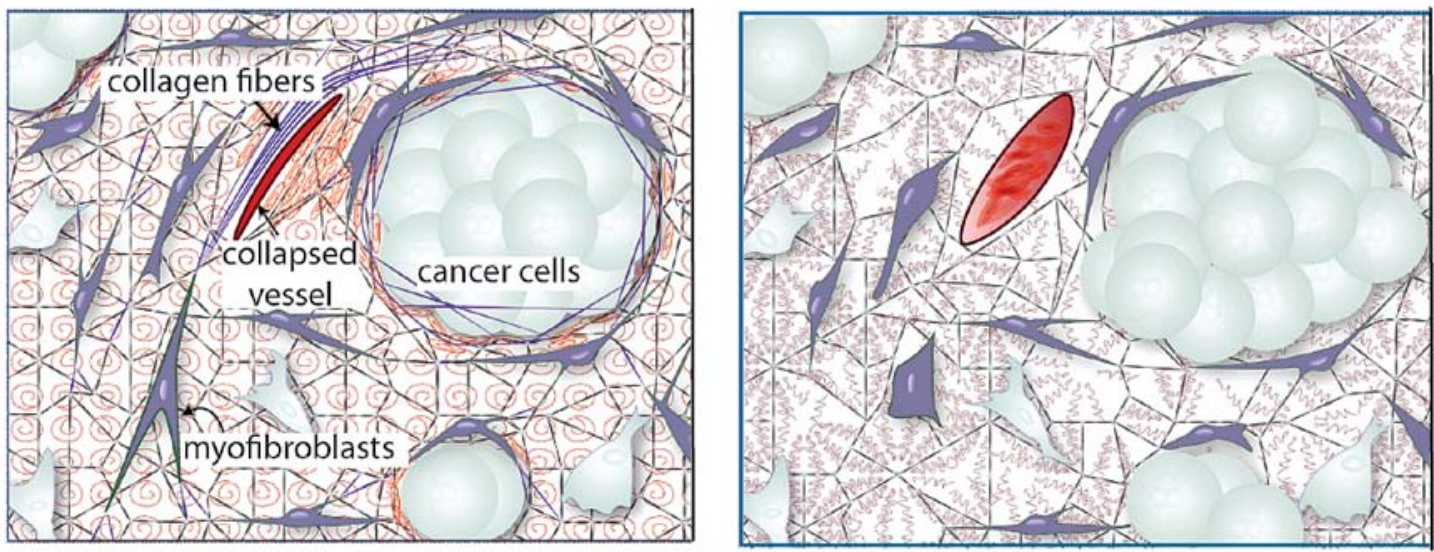

Figure 2. Role of mechanical forces and transforming growth factor $\beta$ (TGF $\beta$ ) in tumor desmoplasia and vessel compression. (A) TGF $\beta$ and mechanical forces contribute to the conversion of fibroblasts to contractile myofibroblasts. Myofibroblast formation results in upregulation of extracellular matrix (ECM) proteins and leads to tumor fibrosis, matrix stiffening and desmoplasia. Increased stiffening of the matrix, in turn, increases the magnitude of the mechanical forces and contributes to further activation of TGF $\beta$ from the ECM. This creates a positive feedback loop, which gives rise to a continuous activation of TGF $\beta$ and formation of myofibroblasts. (B) Upregulation of ECM proteins and the resulting increase in mechanical forces can compress and eventually collapse intratumoral blood vessels. Alleviation of these forces with an anti-TGF $\beta$ agent has the potential to decompress vessels and thus, improve perfusion and drug delivery to solid tumors [adapted with permission from (157)].

move, the interstitial fluid pressure (IFP) increases. Interstitial hypertension is a hallmark of tumor pathophysiology. IFP reaches and even exceeds micro-vascular fluid pressure, which eliminates pressure gradients across the tumor vessel wall and thus, the transvascular transport of drugs (164). Therefore, the only mechanism of transport is through diffusion (i.e., due to a concentration difference), which is inversely proportional to the size of the therapeutic agent. Chemotherapeutic agents, with a size $<1 \mathrm{~nm}$, are able to diffuse fast and exit the tumor vasculature. Nanoparticles, however, with sizes $>60 \mathrm{~nm}$ cannot effectively extravasate into the tumor interstitial space (165).

Furthermore, the dense interstitial matrix of desmoplastic tumors hinders the homogeneous distribution of large nanoparticles. As with transvascular transport, nanoparticles with a size $>60 \mathrm{~nm}$ often cannot penetrate deep into the tumor because their size is comparable to the size of the pores of the interstitial collagen network and they often get trapped (166). Therefore, even if large nanoparticles extravassate from the leaky vessels of the tumor, they will not be able to effectively diffuse into the tissue but they will concentrate in the perivascular regions, causing only local effects. Apart from these steric interactions between the interstitial matrix and nanoparticles, the increased levels of collagen and hyaluronan give rise to electrostatic interactions. Indeed, hyaluronan has a highly negative charge, while collagen fibers carry a slight positive charge. Nanoparticles of a non-neutral surface charge density can be attracted electrostatically and bind to these proteins, which further inhibits their uniform delivery inside the tumor (167).

\section{Therapeutic applications of TGF $\beta$ targeting}

Pharmacological inhibition of TGF $\beta$ has been used in preclinical and clinical studies as a therapeutic strategy to either hinder tumor progression directly or modify the tumor microenvironment in order to improve perfusion and drug delivery and thus, increase indirectly the efficacy of the treatment. There is a large number of TGF $\beta$ inhibitory drugs employed in these studies (137). Particularly, targeting with TGF $\beta$ agents (e.g., 1D11, AP12009, SD-208) as well as non-specific 
targeting with other TGF $\beta$ inhibitory drugs (e.g., tranilast) have shown to reduce tumor progression and metastasis in vivo, mainly owing to augmentation of the immune response and inhibition of EMT $(132,168-171)$. However, there are also studies that relate inhibition of TGF $\beta$ with promotion of tumor progression owing to an increase in inflammatory cell infiltration (172). Particularly, it has been shown that inflammatory infiltrates mediate the pro-tumorigenic functions of fibroblasts that lack TGF $\beta$ signalling. Clinical trials for the use of TGF $\beta$ inhibitory drugs have been in progress (ClinicalTrials.gov identifiers: NCT00368082, NCT01582269 and NCT00844064), but their results are not conclusive yet, presumably owing to differences in the degree of desmoplasia among tumor types or even among tumors of the same type, but also owing to the various effects of TGF $\beta$ on tumor biology.

Targeting of TGF $\beta$ to reduce desmoplasia has the ability to alleviate physical forces in tumors, decompress tumor blood vessels and improve perfusion (Fig. 2B) (160). Restoration of tumor perfusion, however, can increase nutrients supply to the tumor, and thus, increase its growth rate. Also, the decompressed vessels could allow more metastatic cells to leave the primary tumor. Indeed, in some cases, inhibition of TGF $\beta$ has been shown to facilitate tumor progression and metastases in mouse tumor models $(173,174)$, whereas other studies, not related to TGF $\beta$, have shown a correlation between improved perfusion and increased metastases $(175,176)$. Therefore, based on this rationale, judicious doses of TGF $\beta$ inhibitory drugs should be used to alleviate physical forces, decompress blood vessels and improve perfusion when these agents are combined with cytotoxic treatments, such as chemo-, nano-, immuno- and radiotherapy. In these combined treatments the role of the anti-TGF $\beta$ drug is to enhance the delivery of the cytotoxic agent and thus, optimize its efficacy. This therapeutic strategy is known as stress alleviation treatment $(156,163,165)$.

Detailed in vivo studies have shown that re-purposing the anti-hypertensive, angiotensin receptor blocker (ARB) drug losartan reduced expression of TGF $\beta 1$ and decreased stromal collagen and hyaluronan production, in doses that did not affect blood pressure. Reduction of collagen and hyaluronan, in turn, reduced stress levels in the tumor decompressing intratumoral blood vessels and improving perfusion. Furthermore, reduction of the ECM components improved the interstitial fluid flow and thus, reduced levels of IFP. Improved perfusion and reduced IFP enhanced the delivery and efficacy of chemotherapy in orthotopic breast and pancreatic murine tumor models (160). Also, in another study combined treatment of mice bearing tumors with losartan and nanomedicine (Doxil) increased the distribution of the drug and the overall survival of the mice (177). Furthermore, retrospective analyses of clinical data have shown increased survival in patients with lung or renal cancers treated with ARBs $(178,179)$. Similar retrospective analysis has shown that patients with pancreatic ductal adenocarcinomas (PDACs) receiving ARBs survived $\sim 6$ months longer than those who did not (180). These preclinical and clinical data have led to a phase II clinical trial with losartan and FOLFIRINOX in PDAC patients (ClinicalTrials. gov identifier NCT01821729). Apart from the use of ARBs, the TGF $\beta$ neutralizing antibody 1D11 improved the distribution and efficacy of therapeutics in breast carcinomas by reducing the tumor stroma (181). Additionally, re-purposing the drug pirfenidone, a TGF $\beta$ inhibitor clinically approved for the treatment of idiopathic pulmonary fibrosis, was shown to suppress desmoplasia in mice bearing pancreatic tumors and improve the efficacy of chemotherapy (182). Apart from chemotherapy, radiation therapy has been also improved after treatment with TGF $\beta$ inhibitors. Efficacy of radiotherapy depends on the oxygenation of the tissue, which is regulated by tumor perfusion $(183,184)$.

\section{Conclusions and future perspectives}

Owing to the pleiotropic effects of TGF $\beta$ on tumor microenvironment and progression, targeting TGF $\beta$ signaling to directly treat tumor growth remains controversial. Recent studies have suggested an alternative therapeutic strategy, which involves the use of anti-TGF $\beta$ agents in a stress alleviation treatment. The scope of this strategy is to hinder but not completely inhibit the activation of TGF $\beta$ ultimately aiming to reduce tumor desmoplasia and particularly the levels of collagen. As described in this review, reduced collagen levels can lead to improved delivery of both chemo- and nano-therapeutics by alleviating mechanical forces and decompressing intratumoral blood vessels. Thus, blocking of TGF $\beta$ can improve indirectly the efficacy of conventional treatments. It is promising that many anti-TGF $\beta$ agents exist that are already clinically approved for other diseases (e.g., ARBs for hypertension). Re-purposing of these drugs can lead to more effective anti-cancer therapies. Therefore, we need to identify safe and well-tolerated pharmaceutical agents that may complement the treatment regimen of cancer patients. Anti-TGF $\beta$ agents are not the only drugs that have the ability to modify the tumor microenvironment. In principle, any clinically approved agent that has the ability to reduce collagen levels could be employed as an alternative strategy. Also, collagen is not the only target for the stress alleviation treatment. Reduction of stromal cells or hyaluronan has also the potential to enhance drug delivery through the same mechanism (157).

\section{Acknowledgements}

We thank Dr Christiana Polydorou for useful discussions. This study received funding from the European Research Council under the European Union's Seventh Framework Programme (FP7/2007-2013)/ERC grant agreement no. 336839-ReEngineeringCancer.

\section{References}

1. Derynck R and Akhurst RJ: Differentiation plasticity regulated by TGF-beta family proteins in development and disease. Nat Cell Biol 9: 1000-1004, 2007.

2. Wakefield LM and Hill CS: Beyond TGF $\beta$ : roles of other TGF $\beta$ superfamily members in cancer. Nat Rev Cancer 13: 328-341, 2013.

3. Massagué J, Seoane J and Wotton D: Smad transcription factors. Genes Dev 19: 2783-2810, 2005.

4. Annes JP, Munger JS and Rifkin DB: Making sense of latent TGFbeta activation. J Cell Sci 116: 217-224, 2003.

5. Gleizes PE, Beavis RC, Mazzieri R, Shen B and Rifkin DB: Identification and characterization of an eight-cysteine repeat of the latent transforming growth factor-beta binding protein-1 that mediates bonding to the latent transforming growth factor-beta1. J Biol Chem 271: 29891-29896, 1996. 
6. Miyazono K, Olofsson A, Colosetti P and Heldin $\mathrm{CH}$ : A role of the latent TGF-beta 1-binding protein in the assembly and secretion of TGF-beta 1. EMBO J 10: 1091-1101, 1991.

7. Saharinen J, Taipale J and Keski-Oja J: Association of the small latent transforming growth factor-beta with an eight cysteine repeat of its binding protein LTBP-1. EMBO J 15: 245-253, 1996.

8. Unsöld C, Hyytiäinen M, Bruckner-Tuderman L and Keski-Oja J: Latent TGF-beta binding protein LTBP-1 contains three potential extracellular matrix interacting domains. J Cell Sci 114: 187-197, 2001.

9. Nunes I, Gleizes PE, Metz CN and Rifkin DB: Latent transforming growth factor-beta binding protein domains involved in activation and transglutaminase-dependent cross-linking of latent transforming growth factor-beta. J Cell Biol 136: 1151-1163, 1997.

10. Lawrence DA, Pircher R, Krycève-Martinerie C and Jullien P: Normal embryo fibroblasts release transforming growth factors in a latent form. J Cell Physiol 121: 184-188, 1984.

11. Crawford SE, Stellmach V, Murphy-Ullrich JE, et al: Thrombospondin-1 is a major activator of TGF-betal in vivo. Cell 93: 1159-1170, 1998.

12. Ribeiro SM, Poczatek M, Schultz-Cherry S, Villain M and Murphy-Ullrich JE: The activation sequence of thrombospondin-1 interacts with the latency-associated peptide to regulate activation of latent transforming growth factor-beta. J Biol Chem 274: 13586-13593, 1999.

13. Dubois CM, Laprise MH, Blanchette F, Gentry LE and Leduc R Processing of transforming growth factor beta 1 precursor by human furin convertase. J Biol Chem 270: 10618-10624, 1995.

14. Sato Y and Rifkin DB: Inhibition of endothelial cell movement by pericytes and smooth muscle cells: activation of a latent transforming growth factor-beta 1-like molecule by plasmin during co-culture. J Cell Biol 109: 309-315, 1989.

15. Yu Q and Stamenkovic I: Cell surface-localized matrix metalloproteinase-9 proteolytically activates TGF-beta and promotes tumor invasion and angiogenesis. Genes Dev 14: 163-176, 2000.

16. Derynck R, Zhang Y and Feng XH: Smads: transcriptional activators of TGF-beta responses. Cell 95: 737-740, 1998.

17. Massagué J: TGF-beta signal transduction. Annu Rev Biochem 67: 753-791, 1998.

18. Riggins GJ, Thiagalingam S, Rozenblum E, et al: Mad-related genes in the human. Nat Genet 13: 347-349, 1996.

19. Lagna G, Hata A, Hemmati-Brivanlou A and Massagué J: Partnership between DPC4 and SMAD proteins in TGF-beta signalling pathways. Nature 383: 832-836, 1996.

20. Nakao A, Imamura T, Souchelnytskyi S, et al: TGF-beta receptor-mediated signalling through Smad2, Smad3 and Smad4. EMBO J 16: 5353-5362, 1997.

21. Heldin $\mathrm{CH}$, Miyazono K and ten Dijke P: TGF-beta signalling from cell membrane to nucleus through SMAD proteins. Nature 390: 465-471, 1997.

22. Bierie B and Moses HL: Tumour microenvironment: TGFbeta: the molecular Jekyll and Hyde of cancer. Nat Rev Cancer 6 506-520, 2006

23. Lewis KA, Gray PC, Blount AL, et al: Betaglycan binds inhibin and can mediate functional antagonism of activin signalling. Nature 404: 411-414, 2000.

24. Wrana JL, Attisano L, Wieser R, Ventura F and Massagué J: Mechanism of activation of the TGF-beta receptor. Nature 370 341-347, 1994

25. Shi Y and Massagué J: Mechanisms of TGF-beta signaling from cell membrane to the nucleus. Cell 113: 685-700, 2003.

26. Miyazono K, Maeda S and Imamura T: BMP receptor signaling: transcriptional targets, regulation of signals, and signaling cross-talk. Cytokine Growth Factor Rev 16: 251-263, 2005

27. Derynck RandZhang YE:Smad-dependent and Smad-independent pathways in TGF-beta family signalling. Nature 425: 577-584, 2003.

28. Abdollah S, Macías-Silva M, Tsukazaki T, Hayashi H, Attisano L and Wrana JL: TbetaRI phosphorylation of Smad2 on Ser465 and Ser467 is required for Smad2-Smad4 complex formation and signaling. J Biol Chem 272: 27678-27685, 1997.

29. Zhang Y, Feng X, We R and Derynck R: Receptor-associated Mad homologues synergize as effectors of the TGF-beta response. Nature 383: 168-172, 1996.

30. Tsukazaki T, Chiang TA, Davison AF, Attisano L and Wrana JL: SARA, a FYVE domain protein that recruits Smad2 to the TGFbeta receptor. Cell 95: 779-791, 1998.

31. Feng XH, Zhang Y, Wu RY and Derynck R: The tumor suppressor Smad4/DPC4 and transcriptional adaptor CBP/p300 are coactivators for smad3 in TGF-beta-induced transcriptional activation. Genes Dev 12: 2153-2163, 1998.
32. Janknecht R, Wells NJ and Hunter T: TGF-beta-stimulated cooperation of smad proteins with the coactivators $\mathrm{CBP} / \mathrm{p} 300$. Genes Dev 12: 2114-2119, 1998.

33. Itoh S, Ericsson J, Nishikawa J, Heldin CH and ten Dijke P: The transcriptional co-activator P/CAF potentiates TGF-beta/Smad signaling. Nucleic Acids Res 28: 4291-4298, 2000.

34. Bai RY, Koester C, Ouyang T, et al: SMIF, a Smad4-interacting protein that functions as a co-activator in TGFbeta signalling. Nat Cell Biol 4: 181-190, 2002.

35. Chen CR, Kang Y, Siegel PM and Massagué J: E2F4/5 and p107 as Smad cofactors linking the TGFbeta receptor to c-myc repression. Cell 110: 19-32, 2002.

36. Kang Y, Chen CR and Massagué J: A self-enabling TGFbeta response coupled to stress signaling: Smad engages stress response factor ATF3 for Id1 repression in epithelial cells. Mol Cell 11: 915-926, 2003.

37. Wotton D, Knoepfler PS, Laherty CD, Eisenman RN and Massagué J: The Smad transcriptional corepressor TGIF recruits mSin3. Cell Growth Differ 12: 457-463, 2001.

38. Akiyoshi S, Inoue H, Hanai J, et al: c-Ski acts as a transcriptional co-repressor in transforming growth factor-beta signaling through interaction with smads. J Biol Chem 274: 35269-35277, 1999.

39. Luo K, Stroschein SL, Wang W, et al: The Ski oncoprotein interacts with the Smad proteins to repress TGFbeta signaling. Genes Dev 13: 2196-2206, 1999.

40. Stroschein SL, Wang W, Zhou S, Zhou Q and Luo K: Negative feedback regulation of TGF-beta signaling by the SnoN oncoprotein. Science 286: 771-774, 1999.

41. Sun Y, Liu X, Eaton EN, Lane WS, Lodish HF and Weinberg RA Interaction of the Ski oncoprotein with Smad3 regulates TGF-beta signaling. Mol Cell 4: 499-509, 1999.

42. Seoane J, Le HV, Shen L, Anderson SA and Massagué J: Integration of Smad and forkhead pathways in the control of neuroepithelial and glioblastoma cell proliferation. Cell 117: 211-223, 2004

43. Pardali K, Kurisaki A, Morén A, ten Dijke P, Kardassis D and Moustakas A: Role of Smad proteins and transcription factor Sp1 in $\mathrm{p} 21$ (Waf1/Cip1) regulation by transforming growth factor-beta. J Biol Chem 275: 29244-29256, 2000.

44. Zhang Y, Feng XH and Derynck R: Smad 3 and Smad4 cooperate with c-Jun/c-Fos to mediate TGF-beta-induced transcription. Nature 394: 909-913, 1998.

45. Lin X, Liang YY, Sun B, et al: Smad6 recruits transcription corepressor CtBP to repress bone morphogenetic protein-induced transcription. Mol Cell Biol 23: 9081-9093, 2003.

46. Peng Y, Zhao S, Song L, Wang M and Jiao K: Sertad1 encodes a novel transcriptional co-activator of SMAD1 in mouse embryonic hearts. Biochem Biophys Res Commun 441: 751-756, 2013.

47. Izutsu K, Kurokawa M, Imai Y, Maki K, Mitani K and Hirai H: The corepressor CtBP interacts with Evi-1 to repress transforming growth factor beta signaling. Blood 97: 2815-2822, 2001.

48. Xi Q, Wang Z, Zaromytidou AI, et al: A poised chromatin platform for TGF- $\beta$ access to master regulators. Cell 147: 1511-1524, 2011.

49. Ross S, Cheung E, Petrakis TG, Howell M, Kraus WL and Hill CS: Smads orchestrate specific histone modifications and chromatin remodeling to activate transcription. EMBO J 25: 4490-4502, 2006.

50. Papageorgis $\mathrm{P}$, Lambert AW, Ozturk S, et al: Smad signaling is required to maintain epigenetic silencing during breast cancer progression. Cancer Res 70: 968-978, 2010.

51. Nakao A, Afrakhte M, Morén A, et al: Identification of Smad7, a TGFbeta-inducible antagonist of TGF-beta signalling. Nature 389: 631-635, 1997.

52. Itóh S, Landström M, Hermansson A, et al: Transforming growth factor betal induces nuclear export of inhibitory Smad7. J Biol Chem 273: 29195-29201, 1998.

53. Hayashi H, Abdollah S, Qiu Y, et al: The MAD-related protein Smad7 associates with the TGFbeta receptor and functions as an antagonist of TGFbeta signaling. Cell 89: 1165-1173, 1997.

54. Ebisawa T, Fukuchi M, Murakami G, et al: Smurf1 interacts with transforming growth factor-beta type I receptor through Smad7 and induces receptor degradation. J Biol Chem 276: 12477-12480, 2001.

55. Kavsak P, Rasmussen RK, Causing CG, et al: Smad7 binds to Smurf2 to form an E3 ubiquitin ligase that targets the TGF beta receptor for degradation. Mol Cell 6: 1365-1375, 2000.

56.Zhang S, Fei T, Zhang L, et al: Smad7 antagonizes transforming growth factor beta signaling in the nucleus by interfering with functional Smad-DNA complex formation. Mol Cell Biol 27 4488-4499, 2007. 
57.Zhang YE: Non-Smad pathways in TGF-beta signaling. Cell Res 19: 128-139, 2009.

58. Hartsough MT and Mulder KM: Transforming growth factor beta activation of $\mathrm{p} 44 \mathrm{mapk}$ in proliferating cultures of epithelial cells. J Biol Chem 270: 7117-7124, 1995.

59. Frey RS and Mulder KM: TGFbeta regulation of mitogen-activated protein kinases in human breast cancer cells. Cancer Lett 117: 41-50, 1997.

60.Papageorgis P, Cheng K, Ozturk S, et al: Smad4 inactivation promotes malignancy and drug resistance of colon cancer. Cancer Res 71: 998-1008, 2011.

61. Finlay GA, Thannickal VJ, Fanburg BL and Paulson KE: Transforming growth factor-beta 1-induced activation of the ERK pathway/activator protein-1 in human lung fibroblasts requires the autocrine induction of basic fibroblast growth factor. J Biol Chem 275: 27650-27656, 2000.

62.Vinals $\mathrm{F}$ and Pouysségur J: Transforming growth factor beta1 (TGF-beta1) promotes endothelial cell survival during in vitro angiogenesis via an autocrine mechanism implicating TGF-alpha signaling. Mol Cell Biol 21: 7218-7230, 2001.

63. Ellenrieder V, Hendler SF, Boeck W, et al: Transforming growth factor betal treatment leads to an epithelial-mesenchymal transdifferentiation of pancreatic cancer cells requiring extracellular signal-regulated kinase 2 activation. Cancer Res 61 4222-4228, 2001.

64. Xie L, Law BK, Chytil AM, Brown KA, Aakre ME and Moses HL: Activation of the Erk pathway is required for TGF-beta1-induced EMT in vitro. Neoplasia 6: 603-610, 2004.

65.Lee MK, Pardoux C, Hall MC, et al: TGF-beta activates Erk MAP kinase signalling through direct phosphorylation of ShcA. EMBO J 26: 3957-3967, 2007.

66. Liao JH, Chen JS, Chai MQ,Zhao S and Song JG: The involvement of p38 MAPK in transforming growth factor beta1-induced apoptosis in murine hepatocytes. Cell Res 11: 89-94, 2001.

67. Kimura N, Matsuo R, Shibuya H, Nakashima K and Taga T: BMP2-induced apoptosis is mediated by activation of the TAK1-p38 kinase pathway that is negatively regulated by Smad6. J Biol Chem 275: 17647-17652, 2000.

68. Bakin AV, Rinehart C, Tomlinson AK and Arteaga CL: p38 mitogen-activated protein kinase is required for TGFbeta-mediated fibroblastic transdifferentiation and cell migration. J Cell Sci 115: 3193-3206, 2002.

69. Hocevar BA, Brown TL and Howe PH: TGF-beta induces fibronectin synthesis through a c-Jun N-terminal kinase-dependent, Smad4-independent pathway. EMBO J 18: 1345-1356, 1999.

70. Yu L, Hébert MC and Zhang YE: TGF-beta receptor-activated p38 MAP kinase mediates Smad-independent TGF-beta responses. EMBO J 21: 3749-3759, 2002.

71. Yamaguchi K, Shirakabe K, Shibuya H, et al: Identification of a member of the MAPKKK family as a potential mediator of TGF-beta signal transduction. Science 270: 2008-2011, 1995.

72. Shim JH, Xiao C, Paschal AE, et al: TAK1, but not TAB1 or TAB2, plays an essential role in multiple signaling pathways in vivo. Genes Dev 19: 2668-2681, 2005.

73. Sorrentino A, Thakur N, Grimsby S, et al: The type I TGF-beta receptor engages TRAF6 to activate TAK1 in a receptor kinase-independent manner. Nat Cell Biol 10: 1199-1207, 2008.

74. Yamashita M, Fatyol K, Jin C, Wang X, Liu Z and Zhang YE: TRAF6 mediates Smad-independent activation of JNK and p38 by TGF-beta. Mol Cell 31: 918-924, 2008.

75.Zhang L, Wang W, Hayashi Y, et al: A role for MEK kinase 1 in TGF-beta/activin-induced epithelium movement and embryonic eyelid closure. EMBO J 22: 4443-4454, 2003.

76. Kim KY, Kim BC, Xu Z and Kim SJ: Mixed lineage kinase 3 (MLK3)-activated p38 MAP kinase mediates transforming growth factor-beta-induced apoptosis in hepatoma cells. J Biol Chem 279: 29478-29484, 2004.

77. Jaffe AB and Hall A: Rho GTPases: biochemistry and biology. Annu Rev Cell Dev Biol 21: 247-269, 2005.

78. Bhowmick NA, Ghiassi M, Bakin A, et al: Transforming growth factor-beta1 mediates epithelial to mesenchymal transdifferentiation through a RhoA-dependent mechanism. Mol Biol Cell 12: 27-36, 2001.

79. Edlund S, Landström M, Heldin $\mathrm{CH}$ and Aspenström $\mathrm{P}$. Transforming growth factor-beta-induced mobilization of actin cytoskeleton requires signaling by small GTPases Cdc42 and RhoA. Mol Biol Cell 13: 902-914, 2002.

80. Ozdamar B, Bose R, Barrios-Rodiles M, Wang HR, Zhang Y and Wrana JL: Regulation of the polarity protein Par6 by TGFbeta receptors controls epithelial cell plasticity. Science 307: $1603-1609,2005$.
81. Bakin AV, Tomlinson AK, Bhowmick NA, Moses HL and Arteaga CL: Phosphatidylinositol 3-kinase function is required for transforming growth factor beta-mediated epithelial to mesenchymal transition and cell migration. J Biol Chem 275 : 36803-36810, 2000

82. Shin I, Bakin AV, Rodeck U, Brunet A and Arteaga CL: Transforming growth factor beta enhances epithelial cell survival via Akt-dependent regulation of FKHRL1. Mol Biol Cell 12: 3328-3339, 2001

83. Hidalgo $M$ and Rowinsky EK: The rapamycin-sensitive signal transduction pathway as a target for cancer therapy. Oncogene 19: 6680-6686, 2000 .

84.Lamouille S and Derynck R: Cell size and invasion in TGF-beta-induced epithelial to mesenchymal transition is regulated by activation of the mTOR pathway. J Cell Biol 178: 437-451, 2007.

85. Roberts $\mathrm{AB}$ and Wakefield LM: The two faces of transforming growth factor beta in carcinogenesis. Proc Natl Acad Sci USA 100: 8621-8623, 2003.

86. Tang B, Vu M, Booker T, et al: TGF-beta switches from tumor suppressor to prometastatic factor in a model of breast cancer progression. J Clin Invest 112: 1116-1124, 2003.

87. Wakefield LM and Roberts AB: TGF-beta signaling: positive and negative effects on tumorigenesis. Curr Opin Genet Dev 12: $22-29,2002$

88. Siegel PM, Shu W, Cardiff RD, Muller WJ and Massagué J: Transforming growth factor beta signaling impairs Neu-induced mammary tumorigenesis while promoting pulmonary metastasis. Proc Natl Acad Sci USA 100: 8430-8435, 2003.

89. Siegel PM and Massagué J: Cytostatic and apoptotic actions of TGF-beta in homeostasis and cancer. Nat Rev Cancer 3 . 807-821, 2003

90. Choi ME and Ballermann BJ: Inhibition of capillary morphogenesis and associated apoptosis by dominant negative mutant transforming growth factor-beta receptors. J Biol Chem 270: 21144-21150, 1995

91. Hyman KM, Seghezzi G, Pintucci G, et al: Transforming growth factor-betal induces apoptosis in vascular endothelial cells by activation of mitogen-activated protein kinase. Surgery 132: 173-179, 2002.

92.Rich JN, Zhang M, Datto MB, Bigner DD and Wang XF: Transforming growth factor-beta-mediated p15(INK4B) induction and growth inhibition in astrocytes is SMAD3-dependent and a pathway prominently altered in human glioma cell lines. J Biol Chem 274: 35053-35058, 1999.

93. Yang X, Letterio JJ, Lechleider RJ, et al: Targeted disruption of SMAD3 results in impaired mucosal immunity and diminished $\mathrm{T}$ cell responsiveness to TGF-beta. EMBO J 18: 1280-1291, 1999.

94. Laiho M, DeCaprio JA, Ludlow JW, Livingston DM and Massagué J: Growth inhibition by TGF-beta linked to suppression of retinoblastoma protein phosphorylation. Cell 62: $175-185,1990$

95.Hannon GJ and Beach D: p15INK4B is a potential effector of TGF-beta-induced cell cycle arrest. Nature 371: 257-261, 1994.

96. Datto MB, Li Y, Panus JF, Howe DJ, Xiong Y and Wang XF: Transforming growth factor beta induces the cyclin-dependent kinase inhibitor $\mathrm{p} 21$ through a p53-independent mechanism. Proc Natl Acad Sci USA 92: 5545-5549, 1995.

97. Polyak K, Kato JY, Solomon MJ, et al: p27Kip1, a cyclin-Cdk inhibitor, links transforming growth factor-beta and contact inhibition to cell cycle arrest. Genes Dev 8: 9-22, 1994.

98. Pietenpol JA, Stein RW, Moran E, et al: TGF-beta 1 inhibition of c-myc transcription and growth in keratinocytes is abrogated by viral transforming proteins with pRB binding domains. Cell 61: $777-785,1990$

99. Norton JD: ID helix-loop-helix proteins in cell growth, differentiation and tumorigenesis. J Cell Sci 113: 3897-3905, 2000

100. Grotendorst GR: Connective tissue growth factor: a mediator of TGF-beta action on fibroblasts. Cytokine Growth Factor Rev 8: 171-179, 1997.

101.Park K, Kim SJ, Bang YJ, et al: Genetic changes in the transforming growth factor beta (TGF-beta) type II receptor gene in human gastric cancer cells: correlation with sensitivity to growth inhibition by TGF-beta. Proc Natl Acad Sci USA 91: 8772-8776, 1994.

102. Kim IY, Ahn HJ, Zelner DJ, et al: Genetic change in transforming growth factor beta (TGF-beta) receptor type I gene correlates with insensitivity to TGF-beta 1 in human prostate cancer cells. Cancer Res 56: 44-48, 1996. 
103. Markowitz S, Wang J, Myeroff L, et al: Inactivation of the type II TGF-beta receptor in colon cancer cells with microsatellite instability. Science 268: 1336-1338, 1995.

104. Riggins GJ, Kinzler KW, Vogelstein B and Thiagalingam S: Frequency of Smad gene mutations in human cancers. Cancer Res 57: 2578-2580, 1997.

105. Schutte M, Hruban RH, Hedrick L, et al: DPC4 gene in various tumor types. Cancer Res 56: 2527-2530, 1996.

106. Eppert K, Scherer SW, Ozcelik H, et al: MADR2 maps to 18q21 and encodes a TGFbeta-regulated MAD-related protein that is functionally mutated in colorectal carcinoma. Cell 86 543-552, 1996.

107.Hahn SA, Hoque AT, Moskaluk CA, et al: Homozygous deletion map at 18q21.1 in pancreatic cancer. Cancer Res 56: 490-494, 1996.

108. Hahn SA, Schutte M, Hoque AT, et al: DPC4, a candidate tumor suppressor gene at human chromosome 18q21.1. Science 271: 350-353, 1996.

109. Thiagalingam S, Lengauer C, Leach FS, et al: Evaluation of candidate tumour suppressor genes on chromosome 18 in colorectal cancers. Nat Genet 13: 343-346, 1996.

110. Schwarte-Waldhoff I, Volpert OV, Bouck NP, et al: Smad4/DPC4-mediated tumor suppression through suppression of angiogenesis. Proc Natl Acad Sci USA 97: 9624-9629, 2000.

111. Kretzschmar M, Doody J, Timokhina I and Massagué J: A mechanism of repression of TGFbeta/ Smad signaling by oncogenic Ras. Genes Dev 13: 804-816, 1999.

112. Kretzschmar M, Doody J and Massagué J: Opposing BMP and EGF signalling pathways converge on the TGF-beta family mediator Smad1. Nature 389: 618-622, 1997

113. Massagué J: Integration of Smad and MAPK pathways: a link and a linker revisited. Genes Dev 17: 2993-2997, 2003.

114. Gomis RR, Alarcón C, Nadal C, Van Poznak C and Massagué J: $\mathrm{C} / \mathrm{EBPbeta}$ at the core of the TGFbeta cytostatic response and its evasion in metastatic breast cancer cells. Cancer Cell 10: 203-214, 2006.

115.Padua D, Zhang XH, Wang Q, et al: TGFbeta primes breast tumors for lung metastasis seeding through angiopoietin-like 4 Cell 133: 66-77, 2008.

116. Thiery JP: Epithelial-mesenchymal transitions in tumour progression. Nat Rev Cancer 2: 442-454, 2002.

117. Yang J, Mani SA, Donaher JL, et al: Twist, a master regulator of morphogenesis, plays an essential role in tumor metastasis. Cell 117: 927-939, 2004.

118. Xu J, Lamouille S and Derynck R: TGF-beta-induced epithelial to mesenchymal transition. Cell Res 19: 156-172, 2009.

119. Cano A, Pérez-Moreno MA, Rodrigo I, et al: The transcription factor snail controls epithelial-mesenchymal transitions by repressing E-cadherin expression. Nat Cell Biol 2: 76-83, 2000.

120. Savagner P, Yamada KM and Thiery JP: The zinc-finger protein slug causes desmosome dissociation, an initial and necessary step for growth factor-induced epithelial-mesenchymal transition. J Cell Biol 137: 1403-1419, 1997.

121. Eger A, Aigner K, Sonderegger S, et al: DeltaEF1 is a transcriptional repressor of E-cadherin and regulates epithelial plasticity in breast cancer cells. Oncogene 24: 2375-2385, 2005.

122. Comijn J, Berx G, Vermassen P, et al: The two-handed E box binding zinc finger protein SIP1 downregulates E-cadherin and induces invasion. Mol Cell 7: 1267-1278, 2001.

123. Thuault S, Valcourt U, Petersen M, Manfioletti G, Heldin CH and Moustakas A: Transforming growth factor-beta employs HMGA2 to elicit epithelial-mesenchymal transition. J Cell Biol 174: 175-183, 2006.

124. Mani SA, Yang J, Brooks M, et al: Mesenchyme Forkhead 1 (FOXC2) plays a key role in metastasis and is associated with aggressive basal-like breast cancers. Proc Natl Acad Sci USA 104: 10069-10074, 2007.

125. Derynck R, Akhurst RJ and Balmain A: TGF-beta signaling in tumor suppression and cancer progression. Nat Genet 29: $117-129,2001$

126. Yang J and Weinberg RA: Epithelial-mesenchymal transition: at the crossroads of development and tumor metastasis. Dev Cell 14: 818-829, 2008

127.Zhu B, Fukada K, Zhu H and Kyprianou N: Prohibitin and cofilin are intracellular effectors of transforming growth factor beta signaling in human prostate cancer cells. Cancer Res 66: 8640-8647, 2006

128. Deckers M, van Dinther M, Buijs J, et al: The tumor suppressor Smad4 is required for transforming growth factor beta-induced epithelial to mesenchymal transition and bone metastasis of breast cancer cells. Cancer Res 66: 2202-2209, 2006.
129. Kang Y and Massagué J: Epithelial-mesenchymal transitions: twist in development and metastasis. Cell 118: 277-279, 2004.

130. Grande JP: Role of transforming growth factor-beta in tissue injury and repair. Proc Soc Exp Biol Med 214: 27-40, 1997.

131. Singer AJ and Clark RA: Cutaneous wound healing. N Engl J Med 341: 738-746, 1999.

132. Pickup M, Novitskiy S and Moses HL: The roles of TGF $\beta$ in the tumour microenvironment. Nat Rev Cancer 13: 788-799, 2013.

133. Dalal BI, Keown PA and Greenberg AH: Immunocytochemical localization of secreted transforming growth factor-beta 1 to the advancing edges of primary tumors and to lymph node metastases of human mammary carcinoma. Am J Pathol 143: 381-389, 1993.

134. Kingsley LA, Fournier PG, Chirgwin JM and Guise TA: Molecular biology of bone metastasis. Mol Cancer Ther 6: 2609-2617, 2007.

135. Prud'homme GJ: Pathobiology of transforming growth factor beta in cancer, fibrosis and immunologic disease, and therapeutic considerations. Lab Invest 87: 1077-1091, 2007.

136. Wrzesinski SH, Wan YY and Flavell RA: Transforming growth factor-beta and the immune response: implications for anticancer therapy. Clin Cancer Res 13: 5262-5270, 2007.

137. Akhurst RJ and Hata A: Targeting the TGF $\beta$ signalling pathway in disease. Nat Rev Drug Discov 11: 790-811, 2012.

138. Flavell RA, Sanjabi S, Wrzesinski SH and Licona-Limón P: The polarization of immune cells in the tumour environment by TGFbeta. Nat Rev Immunol 10: 554-567, 2010.

139. Laouar Y, SutterwalaFS, Gorelik Land Flavell RA: Transforming growth factor-beta controls $\mathrm{T}$ helper type 1 cell development through regulation of natural killer cell interferon-gamma. Nat Immunol 6: 600-607, 2005.

140. Rubtsov YP and Rudensky AY: TGFbeta signalling in control of T-cell-mediated self-reactivity. Nat Rev Immunol 7: 443-453, 2007.

141. Mantovani A, Sozzani S, Locati M, Allavena P and Sica A: Macrophage polarization: tumor-associated macrophages as a paradigm for polarized M2 mononuclear phagocytes. Trends Immunol 23: 549-555, 2002.

142. Gong D, Shi W, Yi SJ, Chen H, Groffen J and Heisterkamp N: TGF $\beta$ signaling plays a critical role in promoting alternative macrophage activation. BMC Immunol 13: 31, 2012.

143. Fridlender ZG, Sun J, Kim S, et al: Polarization of tumor-associated neutrophil phenotype by TGF-beta: "N1" versus "N2" TAN. Cancer Cell 16: 183-194, 2009.

144. Yamaguchi Y, Tsumura H, Miwa M and Inaba K: Contrasting effects of TGF-beta 1 and TNF-alpha on the development of dendritic cells from progenitors in mouse bone marrow. Stem Cells 15: 144-153, 1997.

145. Ramesh S, Wildey GM and Howe PH: Transforming growth factor beta (TGFbeta)-induced apoptosis: the rise \& fall of Bim. Cell Cycle 8: 11-17, 2009.

146. Marcoe JP, Lim JR, Schaubert KL, et al: TGF- $\beta$ is responsible for NK cell immaturity during ontogeny and increased susceptibility to infection during mouse infancy. Nat Immunol 13: 843-850, 2012

147. Wipff PJ, Rifkin DB, Meister JJ and Hinz B: Myofibroblast contraction activates latent TGF-betal from the extracellular matrix. J Cell Biol 179: 1311-1323, 2007.

148. Wipff PJ and Hinz B: Myofibroblasts work best under stress. J Bodyw Mov Ther 13: 121-127, 2009.

149. Tomasek JJ, Gabbiani G, Hinz B, Chaponnier C and Brown RA: Myofibroblasts and mechano-regulation of connective tissue remodelling. Nat Rev Mol Cell Biol 3: 349-363, 2002.

150.Karagiannis GS, Poutahidis T, Erdman SE, Kirsch R, Riddell RH and Diamandis EP: Cancer-associated fibroblasts drive the progression of metastasis through both paracrine and mechanical pressure on cancer tissue. Mol Cancer Res 10: 1403-1418, 2012.

151. Paszek MJ, Zahir N, Johnson KR, et al: Tensional homeostasis and the malignant phenotype. Cancer Cell 8: 241-254, 2005.

152. Samuel MS, Lopez JI, McGhee EJ, et al: Actomyosin-mediated cellular tension drives increased tissue stiffness and $\beta$-catenin activation to induce epidermal hyperplasia and tumor growth. Cancer Cell 19: 776-791, 2011.

153. Branton MH and Kopp JB: TGF-beta and fibrosis. Microbes Infect 1: 1349-1365, 1999.

154. Egeblad M, Rasch MG and Weaver VM: Dynamic interplay between the collagen scaffold and tumor evolution. Curr Opin Cell Biol 22: 697-706, 2010.

155. Smith NR, Baker D, Farren M, et al: Tumor stromal architecture can define the intrinsic tumor response to VEGF-targeted therapy. Clin Cancer Res 19: 6943-6956, 2013. 
156. Stylianopoulos $\mathrm{T}$ and Jain RK: Combining two strategies to improve perfusion and drug delivery in solid tumors. Proc Natl Acad Sci USA 110: 18632-18637, 2013.

157. Stylianopoulos T, Martin JD, Chauhan VP, et al: Causes, consequences, and remedies for growth-induced solid stress in murine and human tumors. Proc Natl Acad Sci USA 109: 15101-15108, 2012.

158.Demou ZN: Gene expression profiles in 3D tumor analogs indicate compressive strain differentially enhances metastatic potential. Ann Biomed Eng 38: 3509-3520, 2010.

159. Tse JM, Cheng G, Tyrrell JA, et al: Mechanical compression drives cancer cells toward invasive phenotype. Proc Natl Acad Sci USA 109: 911-916, 2012.

160. Chauhan VP, Martin JD, Liu H, et al: Angiotensin inhibition enhances drug delivery and potentiates chemotherapy by decompressing tumor blood vessels. Nat Commun 4: 2516, 2013.

161. Facciabene A, Peng X, Hagemann IS, et al: Tumour hypoxia promotes tolerance and angiogenesis via CCL28 and T(reg) cells. Nature 475: 226-230, 2011.

162. Wilson WR and Hay MP: Targeting hypoxia in cancer therapy. Nat Rev Cancer 11: 393-410, 2011.

163. Jain RK, Martin JD and Stylianopoulos T: The role of mechanical forces in tumor growth and therapy. Annu Rev Biomed Eng 16 321-346, 2014

164.Jain RK and Stylianopoulos T: Delivering nanomedicine to solid tumors. Nat Rev Clin Oncol 7: 653-664, 2010.

165. Chauhan VP and Jain RK: Strategies for advancing cancer nanomedicine. Nat Mater 12: 958-962, 2013.

166. Popović Z, Liu W, Chauhan VP, et al: A nanoparticle size series for in vivo fluorescence imaging. Angew Chem Int Ed Engl 49: 8649-8652, 2010.

167. Stylianopoulos T, Poh MZ, Insin N, et al: Diffusion of particles in the extracellular matrix: the effect of repulsive electrostatic interactions. Biophys J 99: 1342-1349, 2010.

168.Zhong Z, Carroll KD, Policarpio D, et al: Anti-transforming growth factor beta receptor II antibody has therapeutic efficacy against primary tumor growth and metastasis through multieffects on cancer, stroma, and immune cells. Clin Cancer Res 16: 1191-1205, 2010

169. Uhl M, Aulwurm S, Wischhusen J, et al: SD-208, a novel transforming growth factor beta receptor I kinase inhibitor, inhibits growth and invasiveness and enhances immunogenicity of murine and human glioma cells in vitro and in vivo. Cancer Res 64: 7954-7961, 2004.

170. Kim S, Buchlis G, Fridlender ZG, et al: Systemic blockade of transforming growth factor-beta signaling augments the efficacy of immunogene therapy. Cancer Res 68: 10247-10256, 2008.

171. Chakrabarti R, Subramaniam V, Abdalla S, Jothy S and Prud'homme GJ: Tranilast inhibits the growth and metastasis of mammary carcinoma. Anticancer Drugs 20: 334-345, 2009.
172. Achyut BR, Bader DA, Robles AI, et al: Inflammation-mediated genetic and epigenetic alterations drive cancer development in the neighboring epithelium upon stromal abrogation of TGF- $\beta$ signaling. PLoS Genet 9: e1003251, 2013.

173. Bragado P, Estrada Y, Parikh F, et al: TGF- $\beta 2$ dictates disseminated tumour cell fate in target organs through TGF- $\beta$-RIII and $\mathrm{p} 38 \alpha / \beta$ signalling. Nat Cell Biol 15: 1351-1361, 2013.

174. Biswas T, Gu X, Yang J, Ellies LG and Sun LZ: Attenuation of TGF- $\beta$ signaling supports tumor progression of a mesenchymal-like mammary tumor cell line in a syngeneic murine model. Cancer Lett 346: 129-138, 2014.

175. Stockmann C, Doedens A, Weidemann A, et al: Deletion of vascular endothelial growth factor in myeloid cells accelerates tumorigenesis. Nature 456: 814-818, 2008.

176. Rhim AD, Mirek ET, Aiello NM, et al: EMT and dissemination precede pancreatic tumor formation. Cell 148: 349-361, 2012.

177. Diop-Frimpong B, Chauhan VP, Krane S, Boucher Y and Jain RK: Losartan inhibits collagen I synthesis and improves the distribution and efficacy of nanotherapeutics in tumors. Proc Natl Acad Sci USA 108: 2909-2914, 2011.

178. Wilop S, von Hobe S, Crysandt M, Esser A, Osieka R and Jost E: Impact of angiotensin I converting enzyme inhibitors and angiotensin II type 1 receptor blockers on survival in patients with advanced non-small-cell lung cancer undergoing first-line platinum-based chemotherapy. J Cancer Res Clin Oncol 135: 1429-1435, 2009.

179. Keizman D, Huang P, Eisenberger MA, et al: Angiotensin system inhibitors and outcome of sunitinib treatment in patients with metastatic renal cell carcinoma: a retrospective examination. Eur J Cancer 47: 1955-1961, 2011.

180. Nakai Y, Isayama H, Ijichi H, et al: Phase I trial of gemcitabine and candesartan combination therapy in normotensive patients with advanced pancreatic cancer: GECA1. Cancer Sci 103: 1489-1492, 2012.

181.Liu J, Liao S, Diop-Frimpong B, et al: TGF- $\beta$ blockade improves the distribution and efficacy of therapeutics in breast carcinoma by normalizing the tumor stroma. Proc Natl Acad Sci USA 109: 16618-16623, 2012

182. Kozono S, Ohuchida K, Eguchi D, et al: Pirfenidone inhibits pancreatic cancer desmoplasia by regulating stellate cells. Cancer Res 73: 2345-2356, 2013.

183. Bouquet F, Pal A, Pilones KA, et al: TGF $\beta 1$ inhibition increases the radiosensitivity of breast cancer cells in vitro and promotes tumor control by radiation in vivo. Clin Cancer Res 17: 6754-6765, 2011.

184.Zhang M, Kleber S, Röhrich M, et al: Blockade of TGF- $\beta$ signaling by the TGF $\beta$ R-I kinase inhibitor LY2109761 enhances radiation response and prolongs survival in glioblastoma. Cancer Res 71: 7155-7167, 2011. 